Annex 



\section{Constitutional Courts and Councils in the Middle East and North Africa: Basic Facts and Figures}

Anja Schoeller-Schletter and Robert Poll

This section aims to provide basic information on a selection of constitutional review bodies in the region, mostly constitutional courts and councils. Whenever possible, the data was checked by members of the respective institutions or legal experts from the country.

1. Algeria: Constitutional Council

2. Bahrain: Constitutional Court

3. Egypt: Supreme Constitutional Court

4. Iraq: Federal Supreme Court

5. Jordan: Constitutional Court

6. Kuwait: Constitutional Court

7. Lebanon: Constitutional Council

8. Mauritania: Constitutional Council

9. Morocco: Constitutional Court

10. Palestine: Supreme Constitutional Court

11. Tunisia: Constitutional Court 


\section{Algeria: Constitutional Council / المجلس الدستوري}

\subsection{Organization}

Established: 1989 (predecessor 1963-1965)

Legal Basis: Constitution of 2016 (amended in November 2020 allowing for the establishment of a "constitutional court"); Regulation Establishing the Operating Rules of the Constitutional Council of April 8, 2016, and its amendments (Rules of Procedure); Presidential decrees, e.g., Presidential Decree No. 89-143 of August 7, 1989, on the Rules Related to the Organization of the Constitutional Council, and its amendments.

Members: 12 (Constitution, art. 183)

Nomination: In accordance with the internal rules of each appointing organism

Appointment: President of the Republic (4), People's National Assembly (2), Council of the Nation (2), Supreme Court (2), Council of State (2) (Constitution, art. 183)

Qualification: Min. age 40, min. practice 15 years; higher education of legal sciences, magistracy, lawyer at Supreme Court, Council of State or in one of the State's higher positions (Constitution, art. 184).

Term: 8 years, non-renewable (Constitution, art. 183)

Rotation: Partial renewal, every 4 years 6 members (Constitution, art. 183)

Removal options: Yes (Rules of Procedure, art. 88)

Retirement age: No

Formations: Always en banc

\subsection{Jurisdiction}

Review of Legislation: Organic laws, ex-ante (mandatory) (Constitution, arts. 141, 144; Internal Regulations, art. 2); Legislation, ex-ante (Constitution, arts. 144, 187). Legislation, ex-post (Constitution, art. 188)

Review of Executive Acts: No

Review of Constitutional Amendments: Yes, alternative to referendum (Constitution, art. 210)

Review of Treaties: Yes (Constitution, arts. 186, 190)

Review of Elections: Yes (Constitution, art. 182)

Review of Disputes: No (Constitution, art. 79)

Const. Interpretation: No

Advisory Opinions: Treaties, laws and regulations (Constitution, arts. 186, 210) 
Other competences: Revision of Parliament's rules of procedure (Constitution, art. 186, Regulations, art. 3); declaration of presidential and parliamentary vacancies (Constitution, arts. 102, 117); in case of vacancy of Presidency of Republic and the Council of Nation, the Pres. of the Constitutional Council assumes functions of Head of State (Constitution, art. 110)

Advisory role: Armistice agreements and peace treaties (Constitution, art. 111); parliamentary mandate extension (Constitution, art. 120); dissolution of Parliament (Constitution, art. 147); monitoring of referenda and elections (Constitution, art. 182)

\subsection{Procedures}

Case load per year: Organic laws: 3; Legislation, ex-post: 2; Review of Elections: 36 ("2019)

Average duration: Legislation: 30 days; Court referral: 4 months and optional 4 months' one-time extension (Constitution, art. 189)

Initiated by: Organic Laws: President of the Republic (Constitution, art. 186); Legislation, ex ante: President of the Republic, President of the Council of the Nation, President of the People's Assembly, Prime Minister, 40 members of the People's National Assembly, 30 members of Council of the Nation (Constitution, art. 187); Legislation, ex post: Referral by Supreme Court, Council of State (Constitution, art. 188)

Expedited procedure: Yes (Constitution, art. 189)

Oral Proceedings: Yes (Rules of Procedure, art. 23)

Reporting Judge: Yes, one or more (Rules of Procedure, art. 36)

Court fees: No

\subsection{Decisions}

Needed Majority: Absolute majority, quorum: 9, casting vote in case of tie: President (Rules of Procedure, arts. 40, 41)

Decisions in name of: The Constitutional Council

Published in: Official journal, and website (Rules of Procedure, art. 96)

Voting results: Not published

Dissenting opinions: Not published

Decision effect: Binding, erga omnes (Constitution, art. 191)

Decision subject: (In)valid, ex nunc (Constitution, art. 191)

Executory: Immediately (Constitution, art. 191)

Declaratory Decisions: Yes 


\section{Babrain: Constitutional Court / المحكمة الدستورية}

\subsection{Organization}

Established: 2002

Legal Basis: Constitution of 2002, art. 106; Law 27 of 2002 Establishing the Constitutional Court (Constitutional Court Law); Law 38 of 2012 Amending the Constitutional Court Law; Law 42 of 2002 Concerning the Judicial Authority (Judicial Authority Law), Law 13 of 1973 Governing Pensions of Government Employees

Members: 7 (Constitution, art. 106)

Nomination: Supreme Council of the Judiciary, recommendation only (Constitution, art. 33 lit. h)

Appointment: King, Royal order (Constitutional Court Law, art. 3; Constitution, art. 33 lit. h)

Qualification: Bahraini citizen with full legal capacity, but Arab non-citizens may be appointed by exception, good reputation and sound character, min. age 40 years, legal qualification, min. practice 15 years (Constitutional Court Law, art. 4)

Term: 5 years, renewable once (Constitutional Court Law, art. 3, as amended 2012)

Rotation: No (Constitutional Court Law, art. 3, as amended 2012)

Removal options: Yes, disciplinary action by a disciplinary panel established by the Supreme Council of the Judiciary (Constitutional Court Law, art. 9; Judicial Authority Law, arts. 34-42)

Retirement age: 70 , but may be extended to 75 by exception pursuant to a Royal order (Law 13 of 1973, art. 1 lit. g)

Formations: En banc or by presence of Court President and minimum of 4 other members (Constitutional Court Law, art. 28)

\subsection{Jurisdiction}

Review of Legislation: Draft Laws, ex-ante; Laws and Regulations, ex-post (Constitution, art. 106; Constitutional Court Law, art. 18)

Review of Executive Acts: No

Review of Constitutional Amendments: No

Review of Treaties: Yes, by review of ratification law (Constitution, art. 37)

Review of Elections: No

Review of Disputes: No

Const. Interpretation: No

Advisory Opinions: No

Other competences: Review of disputes relating to implementation of Constitutional Court rulings (Constitutional Court Law, art. 32) 


\subsection{Procedures}

Case load / year: Varies by year (minimum was 2, maximum 24)

Average duration: Not available

Initiated by: Legislation, ex-ante: King; Legislation, ex-post: By request of the Prime Minister, President of the Shura Council, President of the Chamber of Deputies; by Court referral; by request of a party to an ongoing court dispute (Constitutional Court Law, arts. 17, 18)

Expedited procedure: No

Oral Proceedings: No, unless the Court determines a need for oral arguments (Constitutional Court Law, art. 25)

Reporting Judge: No

Court fees: Yes, 500 BD, approx. 1,326 USD (Constitutional Court Law, art. 27)

\subsection{Decisions}

Needed Majority: Absolute majority, in the case of equal division of votes, the side on which the President of the Court votes prevails (Constitutional Court Law, art. 28)

Decisions in name of: The King (Judicial Authority Law, art. 5)

Published in: The Official Gazette (Constitutional Court Law, art. 31)

Voting results: Not published

Dissenting opinions: Not published

Decision effect: Binding, erga omnes (Constitution, art. 106; Constitutional Court Law, art. 31)

Decision subject: (In)valid, ex tunc (Constitution, art. 106; Constitutional Court Law, art. 30)

Executory: Immediately, set by court (Constitution, art. 106; Constitutional Court Law, art. 30)

Declaratory Decisions: $\mathrm{n} / \mathrm{a}$ 


\section{Egypt: Supreme Constitutional Court / المحكمــة الدستوريــة العليـا}

\subsection{Organization}

Established: 1969 (as "Supreme Court", renamed 1979)

Legal Basis: Constitution of 2014; Law 48 of 1979 Governing the Operations of the Supreme Constitutional Court, and its amendments (Law 48 of 1979)

Members: "sufficient number of members", currently 12 (Law 48 of 1979, art. 3)

Nomination: Chief Justice, General Assembly of the Court, each 50 percent (Law 48 of 1979, art. 5)

Appointment: By presidential decree, after consultation with Supreme Council of the Judicial Bodies (Law 48 of 1979, art. 5)

Qualification: Minimum age 45 years, member of Supreme Court, counselor of equivalent for minimum 5 years, law professors for minimum 8 years, attorneysat-law with practice before Court of Cassation, high administrative court for minimum 10 years (Law 48 of 1979, art. 4)

Term: Until retirement

Rotation: No

Removal options: Referral to retirement by the Court's General Assembly, disciplinary tribunal (Law 48 of 1979, art. 19)

Retirement age: 70 (Law 48 of 1979, art.14)

Formations: Always en banc

\subsection{Jurisdiction}

Review of Legislation: Yes, ex-post, laws and regulations (Law 48 of 1979, art. 25 I)

Review of Executive Acts: No

Review of Constitutional Amendments: No (Law 48 of 1979, art. 25 I)

Review of Treaties: Yes, ex-post, as laws (Constitution, art. 151; Law 48 of 1979, art. 25)

Review of Elections: No

Review of Disputes: Yes, jurisdictional disputes (Law 48 of 1979, art. 25 II)

Const. Interpretation: Yes, laws, presidential decrees with force of law (, arts. 26, 33)

Advisory Opinions: No

Other competences: Final Judgement in cases where two or more other judicial bodies have produced contradictory judgements (Law 48 of 1979, arts. 25 III and 32) 


\subsection{Procedures}

Case load / year: No information

Average duration: No information

Initiated by: Legislation: court referral (Law 48 of 1979, art. 29). Jurisdictional Disputes: any interested party (Law 48 of 1979, art. 31); Const. Interpretation: by Minister of Justice upon request of Prime Minister, Speaker of the People's Assembly, Supreme Council of Judicial Bodies (Law 48 of 1979, art. 33)

Expedited procedure: No

Oral Proceedings: Optional, if deemed necessary (Law 48 of 1979, art. 44)

Reporting Judge: Commissioner's body (Law 48 of 1979, arts. 21-24 and 39-40)

Court fees: Yes, only in cases of court referral (25 EGP/approx. 1.59 USD), with exemption option (Law 48 of 1979, arts. 52-54)

\subsection{Decisions}

Needed Majority: Absolute majority, quorum 7 (Law 48 of 1979, art. 3)

Decisions in name of: The People (Law 48 of 1979, art. 46)

Published in: Official Gazette (Law 48 of 1979, art. 49)

Voting results: Not published

Dissenting opinions: No

Decision effect: Binding, erga omnes (Constitution, art. 195)

Decision subject: (In)valid, ex tunc

Executory: Immediately, set by court

Declaratory Decisions: No 


\section{Iraq: Federal Supreme Court / المحكمة الاتحادية العليا}

\subsection{Organization}

Established: 2005

Legal Basis: Constitution of 2005; Law 30 of 2005 by order of the transitional Government; Law of Administration for the State of Iraq for the Transitional Period of 8 March 2004 (TAL)

Members: 9 (TAL, art. 44)

Nomination: High Judicial Council

Appointment: President (Decree)

\subsection{Jurisdiction}

Review of Legislation: Yes, ex-post (Constitution, art. 93.1; TAL, art. 44)

Review of Ex. Acts: Yes (TAL, art. 44)

Review of Constitutional Amendments: No

Review of Treaties: No

Review of Elections: Yes, single mandates (Constitution, art. 52.2)

Review of Disputes: Yes, executive, jurisdictional (Constitution, arts. 93.4, 7 and 8; $T A L$, art. 44)

Const. Interpretation: Yes (Constitution, art. 93.2)

Other competences: Approve final results of parliamentary elections (Constitution, art. 93.6); Resolve accusations against the President of the Republic, the Prime Minister, or Ministers (Constitution, art. 93.5); Review legal challenges against rulings of Administrative Court, appellate Court (TAL, art. 44)

\subsection{Procedures}

Case load / year: 48 (Review), 122 (Cassation Cases), 33 (Consultations) ("2009)

Initiated by: Legislation: Government, individuals (Constitution, art. 94.3)

\subsection{Decisions}

Decision effect: Binding, erga omnes (Constitution, art. 94) 


\section{Jordan: Constitutional Court / المحكمة الدستورية}

\subsection{Organization}

Established: 2012

Legal Basis: Constitution of 1952; Law 15 of 2012 concerning establishing the Constitutional Court (Constitutional Court Law)

Members: 9 (Law 15 of 2012, art. 5)

Nomination: Process unknown

Appointment: King (Law 15 of 2012, art. 5)

Qualification: Jordanian nationality, no other nationality, min. age 50 years, judge at Court of Cassation, High Court of Justice, professor of law at university, lawyers with min. practice 15 years, one member "specialist" to whom the conditions of Senate membership apply (Constitution, art. 61; Law 15 of 2012, art. 6)

Term: 6 years, non-renewable (Constitution, art. 58; Law 15 of 2012, art. 5)

Rotation: Partial renewal, every 2 years 3 members (Law 15 of 2012, art. 5)

Removal options: Yes, Royal Decree on recommendation by 6 members (Law 15 of 2012, art. 21)

Retirement age: No

Formations: always en banc

\subsection{Jurisdiction}

Review of Legislation: Laws, regulations: ex-post (Constitution, art. 59; Law 15 of 2012, arts. 9 and 11)

Review of Executive Acts: No

Review of Constitutional Amendments: No

Review of Treaties: No

Review of Elections: No

Review of Disputes: No

Const. Interpretation: Yes (Constitution, art. 59; Law 15 of 2012, art. 17)

Advisory Opinions: No

Other competences: No 


\subsection{Procedures}

Case load / year: 4-7

Average duration: 120 days (Law 15 of 2012, arts. 10, 12)

Initiated by: Legislation: Senate, House of Representatives, Council of Minister, court referral, filtered by Court of Cassation (Constitution, art. 60; Law 15 of 2012, arts. 9, 11); Constitutional interpretation: Council of Ministers, majority of one of the chambers of the legislature (Constitution, art. 59; Law 15 of 2012, art. 17)

Expedited procedure: No

Oral Proceedings: No

Reporting Judge: No

Court fees: Yes, 50 JOD, approx. USD 70 (Law 15 of 2012, art. 36; Regulations 67 of 2019 on Fees for Challenging Constitutionality)

\subsection{Decisions}

Needed Majority: 5, quorum: 7 (Constitution, art. 19)

Decisions in name of: The King (Constitution, art. 59)

Published in: Official Gazette (Constitution, art. 59; Law 15 of 2012, art. 16)

Voting results: Published

Dissenting opinions: Not published

Decision effect: Binding, erga omnes (Law 15 of 2012, art. 15)

Decision subject: (In)valid, ex tunc (Law 15 of 2012, art. 15)

Executory: Immediately (Constitution, art. 59; Law 15 of 2012, art. 15)

Declaratory Decisions: No 


\section{Kuwait: Constitutional Court / المحكمة الدستورية}

\subsection{Organization}

Established: 1973

Legal Basis: Constitution of 1962, art. 173; Law 14 of year 1973 Establishing the Constitutional Court (Constitutional Court Law); Law 109 of 2014 Amending the Constitutional Court Law; Law 23 of 1990 Organizing the Judiciary, amended 1996 (Judiciary Law); Law 10 of 1996 Amending the Judiciary Law; Law 14 of 1977 Concerning Grades and Salaries of Judges and Public Prosecutors; 1974 Decree (no number) Issuing the Bylaws of the Constitutional Court; 1974 Decree (no number) with Respect to Judicial Fees

Members: 5, and 2 substitutes (Constitutional Court Law, art. 2)

Nomination: Supreme Judicial Council (Constitutional Court Law, art. 2)

Appointment: Emiri Decree (Constitutional Court Law, art. 2)

Qualification: Kuwaiti Citizenship, Judge at Court of Appeal or Court of Cassation (Constitutional Court Law, art. 2)

Term: For life

Rotation: No

Removal options: Non-removable except pursuant to disciplinary action by a disciplinary council. Display action may be initiated by request of the Minister of Justice, President of the Court, or Public Prosecutor (1996 Amendment to the Judiciary Law, arts. 23, 40 and 41)

Retirement age: 70, mandatory (Law 14 of 1977, art. 9)

Formations: Always en banc (Constitutional Court Law, art. 3)

\subsection{Jurisdiction}

Review of Legislation: Laws, decrees, regulations: ex-post (Constitutional Court Law, art. 1)

Review of Ex. Acts: No

Review of Constitutional Amendments: No

Review of Treaties: Yes, ex-post

Review of Elections: Yes (Constitutional Court Law, art. 1)

Review of Disputes: No

Const. Interpretation: Yes (Constitutional Court Law, art. 1)

Advisory Opinions: No

Other competences: No 


\subsection{Procedures}

Case load / year: No official numbers, estimate $30-40$ cases

Average duration: 3-6 months

Initiated by: Legislation: 1) By request from the National Assembly or Council of Ministers, 2) court referral or by request of party to an ongoing court dispute, 3 ) original constitutional challenge by any natural or legal (e.g. corporate) person with a direct personal interest affected by the law, decree, or regulation in question; Elections: Any person with a specific personal interest in the election. Constitutional Interpretations: Request by the National Assembly or Council of Ministers (Constitutional Court Law, art. 4; 2014 Amendment; Constitutional Court Bylaws, art. 1)

Expedited procedure: No

Oral Proceedings: No, unless the Court determines a need for oral arguments (Constitutional Court Bylaws, art. 11)

Reporting Judge: No

Court fees: Yes, $50 \mathrm{KD}$, winning party is reimbursed for court fees (Judicial Fees Decree of 1974); direct appeals by individuals 5,000 KD, approx.16,000 USD

\subsection{Decisions}

Needed Majority: Absolute Majority (Consitutional Court Law, art. 3)

Decisions in name of: The Emir of Kuwait (Constitution, art. 53)

Published in: Official Gazette (Consitutional Court Law, art. 3; Constitutional Court Bylaws, art. 19)

Voting results: Not published

Dissenting opinions: Published (Consitutional Court Law, art. 3; Constitutional Court Bylaws, art. 17)

Decision effect: Binding, erga omnes (Consitutional Court Law, art. 1)

Decision subject: (In)valid, ex tunc (Consitutional Court Law, art. 6)

Executory: Immediately (Consitutional Court Law, art. 6)

Declaratory Decisions: Yes, constitutional interpretation on request by National Assembly or Council of Ministers (Consitutional Court Law, art. 4; Constitutional Court Bylaws, art. 1) 


\section{Lebanon: Constitutional Council / المجلس الدستوري}

\subsection{Organization}

Established: 1993

Legal Basis: Constitution of 1926, art. 19; Law 250 of July 14, 1993, on the Establishment of the Constitutional Council, and its amendments (Law 250 of 1993); Law 243 of August 7, 2000, regarding the Rules of Procedures of the Constitutional Council (Law 243 of 2000)

Members: 10 (Law 250 of 1993, arts. 2 and 3; Law 243 of 2000, art. 2)

Nomination: Personal submission of candidacy to President of the Constitutional Council (Law 250 of 1993, art. 3 par. 2)

Appointment: Parliament (5), Council of Ministers (5) (Law 250 of 1993, art. 2)

Qualification: Lebanese citizenship (min. 10 years), minimum age 50, maximum age 74 , practice of 25 years as honorary magistrates, university teachers of law, political/administrative sciences, lawyers (Law 250 of 1993, art. 3)

Term: 6 years, non-renewable (Law 250 of 1993, art. 3; Law 243 of 2000, art. 3)

Rotation: Complete renewal (Law 250 of 1993, art. 4)

Removal options: No, but automatic resignation if member misses three consecutive sessions or dual mandate (Law 243 of 2000, art. 19)

Retirement age: No

Formations: Always en banc

\subsection{Jurisdiction}

Review of Legislation: Laws: ex-post, within 15 days of publication (Law 250 of 1993, arts. 1-18)

Review of Executive Acts: No

Review of Constitutional Amendments: No

Review of Treaties: Yes, by review of the ratification law

Review of Elections: Yes, within 24 hours of publication of results for the presidential elections/ 30 days from proclamation of results for parliamentary elections (Law 250 of 1993, art. 23)

Review of Disputes: No

Const. Interpretation: No

Advisory Opinions: No

Other competences: Reception of declarations of wealth submitted by the President of the Republic, Speaker of Parliament, Prime Minister, Ministers and MPs. 


\subsection{Procedures}

Case load / year: up to 7

Average duration: 1 month (legislation), 6-8 months (elections)

Initiated by: Legislation: President of the Republic, Speaker of the Parliament, President of Ministers Council, 10 MPs; Legislation related to matters of religious freedom, education and practice, in addition to personal status laws: Heads of religious communities in addition to other competent authorities (Law 250 of 1993, art. 19)

Expedited procedure: No

Oral Proceedings: No

Reporting Judge: Yes (Law 250 of 1993, art. 20; Law 243 of 2000, art. 35)

Court fees: No

\subsection{Decisions}

Needed Majority: 7 judges, quorum: 8 (Law 250 of 1993, art. 12)

Decisions in name of: The Constitutional Council

Published in: Official Gazette (Law 243 of 2000, art. 52)

Voting results: Published

Dissenting opinions: Published (Law 243 of 2000, art. 12)

Decision effect: Binding, erga omnes (Law 250 of 1993, art. 13; Law 243 of 2000, art. 52)

Decision subject: (In)valid, ex tunc (Law 250 of 1993, art. 22; Law 243 of 2000, art. 37)

Executory: Immediately (Law 250 of 1993, art. 13; Law 243 of 2000, art. 51)

Declaratory Decisions: No 


\section{Mauritania: Constitutional Council / المجلس الدستوري}

\subsection{Organization}

Established: 1991

Legal Basis: Constitution of 1991; Ordinance 92-04 of February 18, 1992, on the Organic Law of the Constitutional Council, amended 2018 (Ordinance Organic Law); Decree 92-043 PR of August 22, 1992 (Decree Rules of Procedure)

Members: 9 (Constitution, art. 81)

Nomination: In accordance with the internal rules of each appointing organism

Appointment: President of the Republic (4); President of the National Assembly

(4); President of the Senate (2) (Constitution, art. 81)

Qualification: Minimum age 35 years (Constitution, art. 81)

Term: 9 years / not-renewable (Constitution, art. 81)

Rotation: Partial renewal (Every 3 years 3 members) (Constitution, art. 81)

Removal options: Yes, by majority vote of Council members, compulsory resignation in case of mandate/activity incompatible with Council membership or loss of civil and political rights, or physical disability that permanently prevents the exercise of functions (Ordinance Organic Law arts. 10, 11; Decree Rules of Procedure, art. 5)

Retirement age: No

Formations: Always en banc

\subsection{Jurisdiction}

Review of Legislation: Organic laws, regulations: mandatory ex-ante; Laws: ex-ante; Pre-constitutional laws which have not been modified, ex-post (Constitution, art. $86,102)$

Review of Executive Acts: No

Review of Constitutional Amendments: No

Review of Treaties: Yes (Constitution, art. 79)

Review of Elections: Yes (Constitution, arts. 49, 84)

Review of Disputes: No

Const. Interpretation: No

Advisory Opinions: Yes (Constitution, art. 39; Ordinance Organic Law, art. 52)

Other competences: Overseeing referendum and proclaim results (Constitution, art. 85); Supervising the election of the President (Constitution, art. 26); declaration of presidential vacancy (Constitution, art. 40); receivability of legislative proposals (Constitution, art. 62) 


\subsection{Procedures}

Case load / year: No information

Average duration: 1 month (Constitution, art. 86)

Initiated by: Legislation: ex-ante: President of the Republic, President of the National Assembly, President of the Senate, 1/3 National Assembly members, 1/3 Senate members (Constitution, art. 86); ex-post: Individual complaint (Constitution, art. 102); Treaties: President of the Republic, President of the National Assembly, President of the Senate, 1/3 Senate members; Elections: Registered voters, candidates (Constitution, art. 79; Ordinance Organic Law, art. 33)

Advisory opinions: President (Constitution, art. 39; Ordinance Organic Law Constitutional Council Law, art. 52)

Expedited procedure: 8 days, on request of President (Constitution, art. 86)

Oral Proceedings: No

Reporting Judge: Yes

Court fees: No

\subsection{Decisions}

Needed Majority: 4 (Ordinance Organic Law , art. 14)

Decisions in name of: The Constitutional Council

Published in: Official Gazette

Voting results: Not published

Dissenting opinions: No

Decision effect: Binding, erga omnes (Constitution, art. 87)

Decision subject: (In)valid, ex tunc (Constitution, art. 87)

Executory: Immediately

Declaratory Decisions: No 


\section{Morocco: Constitutional Court / المحكمة الدستورية}

\subsection{Organization}

Established: 2011

Legal Basis: Constitution of 2011; Organic Law 066-13 of August 13, 2014 establishing the Constitutional Court (Organic Law 066-13)

Members: 12 (Constitution, art. 130)

Nomination: Secretary-General of Superior Council of Ulema (1, appointed by King), Bureau of each Parliamentary Chamber (Constitution, art. 130)

Appointment: King (6), Chamber of Councilors (3), Chamber of Representative (3) (Constitution, art. 130)

Qualification: Minimum practice 15 years, notable persons, high knowledge (formation) in juridical domain, of judicial competence, doctrinal and administrative (Constitution, art. 130)

Term: 9 years, non-renewable (Constitution, art. 130)

Rotation: Partial renewal, every 3 years 4 members (Constitution, art. 130)

Removal options: Yes, Royal decree on recommendation by 6 members (Constitution, art. 130; Organic Law 066-13, art. 12)

Retirement age: No

Formations: Always en banc

\subsection{Jurisdiction}

Review of Legislation: Organic laws, parliamentary rules of procedure, ex-ante (mandatory) (Constitution, art. 132); Other Laws, ex-ante (on initiative); Laws, ex-post (incidental) (Constitution, art. 133)

Review of Executive Acts: No

Review of Constitutional Amendments: No

Review of Treaties: Yes (Constitution, art. 55; Organic Law 066-13, art. 24)

Review of Elections: Yes, elections, referendum (Constitution, arts. 132 and 174)

Review of Disputes: Yes, parliamentary receivability of proposal, domain of law (Constitution, art. 79)

Const. Interpretation: No

Advisory Opinions: Yes, on decrees modifying legislation (Constitution, art. 73)

Other competences: Parliamentary vacancies (Constitution, art. 61) 


\subsection{Procedures}

Case load / year: 23 (2019)

Average duration: Legislation: 30 days; Elections: 1 year (Constitution, art. 121;

Organic Law 066-13, art. 26)

Initiated by: Legislation: King, Head of Government, President of Chamber of Representatives, President of Chamber of Councilors, 1/5 of members of Chamber of Representatives, 40 members of Chamber of Councilors, Court referral. Treaties: King, Head of Government, President of Chamber of Representatives, President of Chamber of Councilors, 1/6 of members of Camber of Representatives, 30 members of Chamber of Councilors (Constitution, arts. 132, 133)

Expedited procedure: Yes, 8 days, on demand of government (Constitution, art. 132) Oral Proceedings: Optional, if deemed necessary (Organic Law 066-13, art. 18)

Reporting Judge: Yes (Organic Law 066-13, art. 17)

Court fees: No

\subsection{Decisions}

Needed Majority: 8, quorum: 9 (Organic Law 066-13, art. 17)

Decisions in name of: The King (Organic Law 066-13, art. 17)

Published in: Official Gazette (Organic Law 066-13, art. 17)

Voting results: Not published

Dissenting opinions: Not published

Decision effect: Binding, erga omnes

Decision subject: (In)valid, ex nunc

Executory: Immediately

Declaratory Decisions: No 


\section{Palestine: Supreme Constitutional Court / المحكمـة الدستوريـة العليـا}

\subsection{Organization}

Established: 2016

Legal Basis: Constitution of 2016, Law of the Supreme Constitutional Court (Law on the $S C C$ )

Members: 9, at least (Law on the SCC, art. 1.1)

Nomination: First formation: High Judicial Council, Minister of Justice (consultation); Subsequent nominations: General Assembly of High Constitutional Court (recommendation) (Law on the SCC, art. 5)

Appointment: President of the State of Palestine (Law on the SCC, art. 5)

Qualification: Minimum age 40 years, current or former member of Supreme Court for at least 3 years, current judge of a Court of Appeal for at least 7 years, current or former univ. professor for at least 3 years, co-professor for 6 years, assoc. professor for 9 years, practicing lawyer for at least 20 years, member of public prosecution for at least 15 years as Chief Prosecutor (Law on the SCC, art. 4)

Term: 6 years, non-renewable (Law on the SCC, art. 2)

Rotation: Partial renewal, every 2 years 3 new members (in accordance with the amendment of the law by Act 7 of 2019). The appointment of 3 members of the Court shall be made every two years as from the date of 1/6/2017 (Law on the SCC, art. 2)

Removal options: By decision of President of National Authority upon recommendation of the Court's General Assembly, losing the legal capacity or competence, disability due to any reason to perform the tasks, crime that violates honor or trust by a definitive judgment, even if rehabilitated (Law on the SCC, art. 21); Referral to Retirement by the Court's General Assembly, Disciplinary Tribunal (Law on the SCC, art. 16)

Retirement age: No

Formations: Always en banc, (Law on the SCC, art. 2)

\subsection{Jurisdiction}

Review of Legislation: Laws, regulations: ex-post (Law on the SCC, art. 24.1)

Review of Executive Acts: No

Review of Constitutional Amendments: No

Review of Treaties: No

Review of Elections: No

Review of Disputes: Yes, Executive and Jurisdictional (Law on the SCC, art. 24.2 C 4) 
Const. Interpretation: Yes (Law on the SCC, art. 24.2 A)

Advisory Opinions: No

Other competences: Resolution and settlement of an appeal concerning the legal incompetence of the president (Law on the SCC, art. 24.5); explaining legislation in cases where there is a conflict in execution (Law on the SCC, art. $24.2 \mathrm{~A}$ and B)

\subsection{Procedures}

Case load / year: 38 ("2019)

Average duration: Within 1 year

Initiated by: Legislation: court referral (Law on the SCC, arts. 27, 28); interpretation: Minister of Justice on request of President or Head of the Legislative Council, or head of the High Judicial Council, or of whom constitutional rights were violated (Law on the SCC, art. 30)

Expedited procedure: No

Oral Proceedings: Yes, not mandatory (Law on the SCC, art. 36)

Reporting Judge: No

Court fees: Yes (100 JOD, approx. 141 USD), with exemption option (financial incapability) (Law on the SCC, arts. 45.1,46)

\subsection{Decisions}

Needed Majority: Absolute majority, quorum: 7 (Law on the SCC, arts. 2.4, 10)

Decisions in name of: Arab Palestinian People (Law on the SCC, arts. 38)

Published in: Official Gazette (Law on the SCC, art. 53)

Voting results: Yes

Dissenting opinions: Yes

Decision effect: Binding, erga omnes (Law on the SCC, art. 41.1)

Decision subject: (In)valid, ex tunc (Law on the SCC, art. 41.1-3)

Executory: Immediately

Declaratory Decisions: No 


\section{Tunisia: Constitutional Court / المحكمة الدستورية}

\subsection{Organization}

Established: Pending

Legal Basis: Constitution of 2014, arts. 118-124; Organic Law 2015-50 of December 3, 2015 Related to the Constitutional Court (Organic Law)

Members: 12 (Constitution, art. 118; Organic Law, art. 7)

Nomination: By the President of the Republic (Organic Law, art. 14)

Appointment: President of Republic (4), Assembly of the Representatives of the People (4), Supr. Judicial Council (4) (Constitution, art. 118; Organic Law, arts. 10-13)

Qualification: Tunisian citizenship for minimum 5 years, minimum age 45, no partisan responsibilities, not been candidate in any elections in past 10 years, not been subject to disciplinary action, clean criminal record; 9 legal experts with minimum practice 20 years: university professors, senior judge, lawyer registered at Court of Cassation, other legal experts with doctorate (or equivalent); 3 experts from other fields with doctorate (or equivalent) (Constitution, art. 118; Organic Law, art. 8)

Term: 9 years, non-renewable (Constitution, art. 118; Organic Law, art. 18)

Rotation: Partial renewal, every 3 years 4 members (Constitution, art. 118; Organic Law, art. 18)

Removal options: By two thirds of the court's members in case that a member loses any of the conditions required to be a candidate for the Constitutional Court or breaches the duties imposed on him/her by the law on the Constitutional Court (Organic Law, art. 20)

Retirement age: No

Formations: Always en banc

\subsection{Jurisdiction}

Review of Legislation: Laws: ex-ante, within 7 days of ratification (Constitution, arts. 120 and 122; Organic Law, arts. 45-53); ex-post (Constitution, arts. 120 and 123; Organic Law, arts. 54-61)

Review of Executive Acts: No

Review of Constitutional Amendments: Yes: ex-ante (Constitution, arts. 120 and 144; Organic Law, arts. 40-42)

Review of Treaties: Yes, ex-ante (Constitution, art. 120; Organic Law, art. 43)

Review of Elections: No

Review of Disputes: Yes, between President and Head of Government (Constitution, art. 101; Organic Law, arts. 74-76) 
Const. Interpretation: No

Advisory Opinions: No

Other competences: Review of State of Emergency (Constitution, art. 80; Organic Law, arts. 72-73); Declaration of presidential vacancy (Constitution, art. 84; Organic Law, arts. 69 and 70); Impeachment of President (Constitution, art. 88; Organic Law, arts. 65-68); Review of Rules of Procedure of Assembly of the Representatives of the People (Constitution, art. 120; Organic Law, arts. 62-64); Interim President takes oath in front of the CC (in the event of dissolution of the Assembly of representatives of the people) (Constitution, art. 85; Organic Law, art. 71)

\subsection{Procedures}

Case load / year: -

Average duration: Legislation (ex ante), Constitutional Amendments, Treaties: 45 days (Constitution, art. 121; Organic Law, arts. 42, 44 and 52); Legislation (ex post): 3 months (Constitution, art. 123; Organic Law, art. 60); Disputes: 7 days (Constitution, art. 101; Organic Law, art. 76)

Initiated by: Legislation, ex ante: President of the Republic, Head of Government, 30 Members of Assembly of the Rep. of the People (Constitution, arts. 120, 122; Organic Law, arts. 45-53). Legislation, ex post: Court referral (Constitution, arts. 120, 123; Organic Law, art. 61). Constitutional Amendments: President of the Assembly of the Representatives of the People (mandatory) (Constitution, arts. 120,144; Organic Law, art. 42). Treaties: President of the Republic (mandatory)

(Constitution, art. 120; Organic Law, art. 43)

Expedited procedure: Yes, legislation, ex ante: 2 days (Organic Law, art. 52)

Oral Proceedings: Yes (Organic Law, art. 36)

Reporting Judge: Yes, 2 (Organic Law, art. 38)

Court fees: No

\subsection{Decisions}

Needed Majority: Absolute majority (Constitution, art. 121; Organic Law, arts. 5, 60) Decisions in name of: The People (Organic Law, art. 5)

Published in: Official Gazette, and on Website (Constitutional Court Law, art. 5)

Voting results: Not published

Dissenting opinions: No, but option to publish comment on decision by the court in a specialized legal journal (Organic Law, art. 27)

Decision effect: Binding, erga omnes, exception: electoral laws (Organic Law, art. 7) 
Decision subject: (In)valid, ex nunc, ex tunc (electoral laws) (Organic Law, art. 60) Executory: Immediately

Declaratory Decisions: No 
